TITLE:

\title{
Induction of Endotoxin Tolerance in Transgenic Mouse Liver Expressing Creatine Kinase( Abstract_要旨 )
}

\author{
$\operatorname{AUTHOR}(\mathrm{S})$ :
}

Hatano, Eturou

\section{CITATION:}

Hatano, Eturou. Induction of Endotoxin Tolerance in Transgenic Mouse Liver Expressing Creatine Kinase. 京都大学, 1997, 博士(医学)

ISSUE DATE:

1997-03-24

URL:

http://hdl.handle.net/2433/202189

RIGHT: 
氏名波䇟野祱朗

学位(専攻分野) 博士（医 学）

学位記番号医 博 第 1872 号

学位授与の日付 平成 9 年 3 月 24 日

学位授与の要件 学 位 規 則 第 4 条第 1 項該 当

研究科・専攻医学研究科外科系専攻

学位論文題目 Induction of Endotoxin Tolerance in Transgenic Mouse Liver Expressing Creatine Kinase

(クレアチンキナーゼを肝特異的に発現させたトランスジェニック マウスにおけるエンドトキシン嗽性の誘導に関する研究）

論文調查委員教授 今村正之教授中西重忠教授西川伸一 教授 山岡義生

\section{論文内容 の 要 旨}

[序論] 最近の分子生物学の進歩により, 生体への遺伝子導入が可能となり, 元来, 肝臟では低発現の遺 伝子を遺伝子導入することにより，肝臓の様々な機能を強化し，外科における周術期の病態改善が，期待 できる。術後の敗血症, 多臟器不全は, 外科患者の主な死亡原因の一つで, 過剩なサイトカイン反応が起 こり全身の臓器を障害するが，その中でも肝臟は第一標的臟器である。エンドトキシンショックにおいて 肝細胞は, 肝ミトコンドリアの障害や微小循環障害を受け, 肝臟の ATP, energy charge（EC）が低下 することが知られている。

肝臟以外の臟器（筋肉, 脳, 心蔵)でATP のリザーバーとして phosphocreation (PFr) / creatine (Cr) 系を触媒する䣼素であるクレアチンキナーゼを肝特異的に発現させたトランスジェニックマウス (CK-TGmice) は, phosphocreatine のリザーバーの作用により，エンドトキシンショックにおける ATP, EC の低下を軽減させることが期待出来るので, lipopolysaccharide (LPS)に対する CK-TGmice の耐性について検討した。

[方法] (1) CK-TG mice は prealbumin の transthyretin gene の promotor を用い rat brain creatine kinase gene を肝特異的に発現させたもので，通常食飼育 CK-TGmice を $\mathrm{PCr}$ (一) 群（コントロール）とし， LPS 投与前 5 日間 $10 \% \mathrm{Cr}$ 今飼育群を $\mathrm{PCr}(+)$ 群とした。CK-TGmice は, 通常食では肝膩に $\mathrm{PCr}$ の 集積を認めないが， 5 日間 $10 \% \mathrm{Cr}$ 食投与で $10.63 \pm 2.18$ vs. $0.17 \pm 0.06 \mu \mathrm{mol} / \mathrm{g}$ liver $(\mathrm{PCr}(+)$ 群 vs. $\mathrm{PCr}($ ）群と肝渽に $\mathrm{PCr}$ の集積を認めた。

(2)このCK-TGmiceを用い，敗血症のモデルとして(1)LPS: 0.5, 1, 5, 10,25, $100 \mathrm{mg} / \mathrm{kg}$ をi.p. し 生存率を比較した。また以下 LPS $10 \mathrm{mg} / \mathrm{k}$ gi. p. にて(2)Endospecyによる血中エンドキシン濃度, (3) ELISA による TNF $\alpha$ ，IL- $1 \alpha ， I L-6 ，(4) \mathrm{HPLC} に よ る$ 肝組織中の Cr，PCr，ATP，ADP，AMP 及びEC， 
(5)血糖值及び，(6)酸素電極による肝ミトコンドリアのリン酸化能の測定を行った。

[結果] (1) LPS10 mg/kg i. p. 後72 h の生存率は $80 \%$ vs. $24 \%$ とCr $(+)$ 群で高く $(P<0.01), \mathrm{LD}_{50}$ は 7.46 vs. $13.83 \mathrm{mg} / \mathrm{kg}$ と有意差を認めた（ $P<0.05 ）$ 。(2)血中エンドトキシン濃度に差はないものの，(3) サイトカインは LPS i. p. 後の $4 \mathrm{~h}$ の IL- $1 \alpha$ 及び NTF $\alpha$ で PCr $(+)$ 群が低值であった $(P<0.05) 。(4)$ LPS $48 \mathrm{~h}$ 後の ATP, EC は $3.16 \pm 0.21$ vs. $2.76 \pm 0.32 \mu \mathrm{mol} / \mathrm{g}$ liver, $0.843 \pm 0.010$ vs. $0.745 \pm 0.024$ ( $P$ <0.005）と PCr（+）群で ATP， EC は良好に保たれていた。(5) LPS i. p. 後48 h において PCr（+） 群で血糖の低下は抑制されていた。(6)肝ミトコンドリアのリン酸化能はPCr（+）群で LPS i. p. 後もコ ントロールレベルに保たれていた。

[考察] PCrの存在によるミトコンドリア ATP生成能の維持とサイトカイン反応の軽減効果の機序によ り，LPSによる侵襲に対し肝細胞が保護された結果，生存率が改善したものと思われた。これらの結果 より, クレアチンキナーゼの遺伝子導入は，周術期における肝臓強化の方法として有用であると考えられ た。

\section{論文審查の結果の要旨}

敗血症において肝細胞は, 肝ミトコンドリアの障害や微小循環障害を受け, 肝エネルギー代謝不全に陥 る。筋肉等で ATP のリザーバーとして phosphocreatine (PCr) / creatine (Cr) 系を触媒する creatine kinase (CK) を肝特異的に発現させたトランスジェニックマウス（CK-TGmice）は，PCrの作用により 敗血症における肝ATP level の維持が期待出来るので, lipopolysaccharide (LPS)に対する CK-TGmice の酎性について通常食飼育群と $10 \% \mathrm{Cr}$ 食飼育群に分け比較した。

LPS $10 \mathrm{mg} / \mathrm{kg}$ i. p. $4 \mathrm{~h}$ 後の TNF $\alpha$ 及び IL- $1 \alpha$ は, Cr 食飼育群が低值で, LPS 投与後の ATP, energy charge は Cr 食飼育群で良好に保たれていた。肝ミトコンドリアのリン酸化能の維持, 低血糖の抑制が $\mathrm{Cr}$ 食飼育群でみられた。生存率は $80 \%$ vs. $24 \%$ と Cr 食飼育群で高く， $\mathrm{LD}_{50}$ に扔いても有意差を認めた。

$\mathrm{PCr}$ の存在による肝臓の高エネルギー状態とサイトカイン反応の軽減効果により，LPSによる侵襲に 対し肝細胞が保護された結果, 生存率が改善したものと思われた。

以上の研究は, エンドトキシンに対する肝臓のエネルギー代謝不全の解明に貢献し, 敗血症の治療に寄 与するところが多い。

したがって，本論文は博士（医学）の学位論文として価值あるものと認める。

なお, 本学位授与申請者は, 平成 9 年 2 月 10 日実施の論文内容とそれに関連した試問を受け, 合格と認 められたものである。 